\title{
Durability of Soil-Cement Blocks with the Incorporation of Limestone Residues from the Processing of Marble ${ }^{\dagger}$
}

\author{
Bruno Rangel França ${ }^{a}$, Afonso Rangel Garcez Azevedo ${ }^{a}$, Sergio Neves Monteiro ${ }^{b}$, Fabio Da Costa \\ Garcia Filho $^{b * \mathbb{D}, \text { Markssuel Teixeira Marvila }}$, Jonas Alexandre $^{a}$, Euzébio Bernabé Zanelato ${ }^{a}$ \\ ${ }^{a}$ Departamento de Engenharia Civil, Universidade Estadual do Norte Fluminense Darcy Ribeiro, \\ 28013-600, Campos dos Goytacazes, RJ, Brasil \\ ${ }^{b}$ Departamento de Ciência dos Materiais, Instituto Militar de Engenharia - IME, Praça General \\ Tibúrcio, 22290-270, Rio de Janeiro, RJ, Brasil
}

Received: December 20, 2017; Revised: April 08, 2018; Accepted: April 20, 2018

\begin{abstract}
The great environmental impact caused by mineral production has forced mining and ornamental stone industries to acquire new concepts and technical solutions in order to develop eco-friendly and sustainable activities. In this context, this work aims to study the durability of soil-cement block with the incorporation of limestone residues from the processing of marble as an ornamental stone. Specimens were prepared with 30,40 and 50 vol\% of residues added to the soil-cement mixture and analyzed for their physical, chemical and mineralogical properties. After the curing period, the specimens were subjected to mechanical analysis and the established experimental program showed that the addition of residues in the mixture becomes feasible for the preparation of soil-cement blocks, exhibiting improved results when compare to a reference block without residues.
\end{abstract}

Keywords: Soil-cement, Limestone residues from marble processing, Durability.

\section{Introduction}

In the last three decades, the ornamental stone sector has been one of the fastest growing industrial activities in Brazil. The Brazilian production reached the equivalent of $10,500,000$ tons in 2013, with domestic consumption of 7,880,000 tons equivalent to 78.00 million $\mathrm{m}^{2}$ of sawed slabs, in which more than 16.5 million $\mathrm{m}^{2}$ correspond to marbles ${ }^{1}$. As a result of the great production of ornamental stone, tons of residues are generated and would occupy a great amount of open spaces. Therefore, they are usually being discarded outside the industry, which contribute to environmental pollution. In this marble processing step, approximately $30 \%$ of slabs are transformed into limestone residues in the form of small particles and powder classified as inert and non-biodegradable ${ }^{2}$. The adoption of practices for a reuse and recycling of this type of residues to avoid environmental pollution is mostly desirable as it contributes to sustainable development. The civil construction industry appears as the best solution to overcome this environmental issue and the incorporation of limestone residues in cement blocks can also result in a cost reduction of the fabricated products since the residues are considered waste materials for the industry ${ }^{3}$.

The modular constructions of pressed blocks of soil-cement are currently being emphasizing and gaining space in the civil construction, since these blocks present great advantages when compare to standard ceramics brick

*e-mail: fabiogarciafilho@gmail.com

Article presented in the ABM Week 2017, October 2nd to 6th, 2017, São Paulo, SP, Brazil constructions ${ }^{4}$. This type of construction is made by fitting male and female type of blocks in a constructive process that minimizes wastes, since all construction is planned from the beginning to the end ${ }^{5}$. The press-fit block is a product that can incorporate discarded residues of different types and origins in its production. In many cases, addition of these types of materials brings not only technical advantages but also reduces the costs of the final product ${ }^{5}$.

Several research articles on the incorporation of residuess, generated by the ornamental stone industries, specially those dedicated to marbles and granites, have been published since last decade ${ }^{6-12}$. These articles aim to contribute to the sustainable development by making greater use of industrial residuess in the civil construction as mortars ${ }^{6}$, bricks ${ }^{7,8}$, concrete $^{9,10}$, blocks ${ }^{11}$ and ceramic grouting ${ }^{12}$. Considering the complexity of degradation mechanisms that impair the useful life of construction products and the high costs of civil works, the evaluation of the durability of a product is certainly one of the most important aspects in the development of a new construction material ${ }^{13}$. Durability can be defined as the ability of a material to maintain its integrity when under actions of environmental agents. The preservation of properties is substantial to justify the performance of the product over its useful life ${ }^{4}$. One of the several ways considered to evaluate the durability of a material is to quantify, through tests of long drying and wetting cycles, the mass loss and dimensional variation. 
Therefore, this work aims to investigate the durability of soil-cement blocks with the incorporation of limestone residues from the processing of marble. The objective is to present alternatives in the manufacture of sustainable soil-cement blocks. This represents another possible destination of limestone residues towards the adoption of more environmentally correct construction techniques.

\section{Methodology}

For this study, the following materials were used: sand clay soil from Campos dos Goytacazes-RJ, Brazil, classified as per ABNT (Brazilian Association of Technical Standards) No. 8 sieve (2.34 mm); limestone residues from the processing of the marble that was collected at the Polita Mármores industry, located in the city of Cachoeiro do Itapemirim, state of Espirito Santo, Brazil. The as-collected residues were in the form of a mud, and had to be naturally dry outdoors at room temperature for 7 days in order to eliminate the excess of moisture. The dry mud was further beneficiated by sieve to $0.074 \mathrm{~mm}$ according to the Brazilian Association of Technical Standards ABNT No. 40. A Portland cement, model CP V, of the Nassal company produced in Brazil was used as basic matrix. It has compatible physical, chemical and mechanical characteristics for the production of soil-cement blocks. Its choice was due to desirable characteristics regarding the initial fast resistance gain with time, which allowed a better transportation logistics of the blocks after molding to carry out the tests.

Initially the marble processing limestone residues was physically characterized by specific loss of mass, particle size and Atterberg boundaries. It was also chemically characterized by fluorescence X-rays analysis (XRF) in a Shimadzu EDX-700 equipment. For the mineralogical characterization, X-ray diffraction (XRD) was performed in a Shimadzu XRD-6000 equipment. Then, based on others studies $^{14,15}$, the dosage of the mixtures was established, fixing the maximum Portland cement content in $10 \%$ of the total mass and partially replacing the clay soil (small aggregate) with the limestone residues in the proportions of 30,40 and $50 \mathrm{vol} \%$. All compositions were compared to the reference (control) sample without residues. Table 1 presents the composition of the investigated soil-cement mixtures.

Table 1. Compositions (vol\%) of the soil-cement mixtures

\begin{tabular}{lccc}
\hline Mixtures & $\begin{array}{c}\text { Limestone } \\
\text { residues }\end{array}$ & Clay Soil & $\begin{array}{c}\text { Portland } \\
\text { Cement }\end{array}$ \\
\hline Control $(0 \%)$ & 0 & 90 & 10 \\
$30 \%$ residues & 30 & 60 & 10 \\
$40 \%$ residues & 40 & 50 & 10 \\
$50 \%$ residues & 50 & 40 & 10 \\
\hline
\end{tabular}

Blocks made with different mixtures were molded in the dimensions of $30 \times 15 \times 7 \mathrm{~cm}^{3}$ in a hydraulic press, under 15 tons of pressure and molding humidity of $16 \%$ for compaction tests as per Brazilian Standard NBR $12023^{16}$. Figure 1 (a) illustrates the production of the blocks and (b) the produced block. The curing process was performed in a humid chamber at a controlled temperature of $23^{\circ} \mathrm{C}$ and $95 \%$ humidity over a period of 7 days.

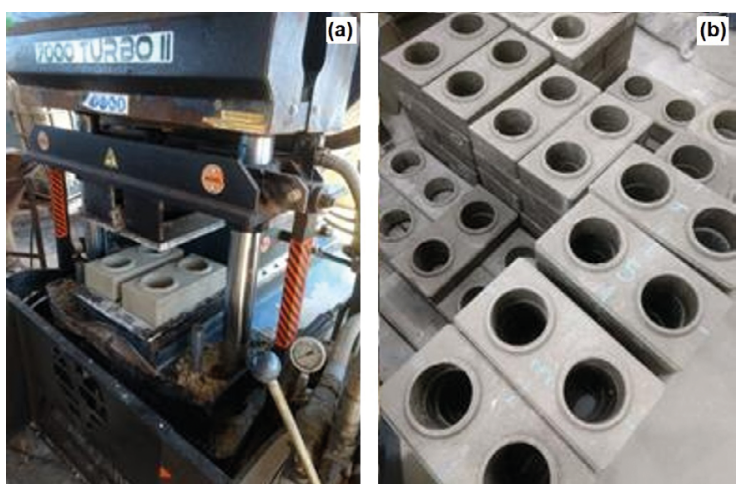

Figure 1. Soil-cement blocks with limestone residues from marble processing (a) production and (b) finished blocks

The methodology used to perform the accelerated degradation test (durability by wetting and drying) was based on the Brazilian Standard NBR $13554{ }^{17}$. Others tests were performed to better evaluate the degradation parameters, the water absorption determination and the simple compression resistance as per Brazilian Standard NBR $10836^{18}$, whose results were compared with those of the samples subjected to degradation and those not degraded.

18 specimens were produced for each condition, which leads to a total of 72 tested units. For each condition, 6 units were tested for simple compression, 6 units for the water absorption test and 6 units were subjected to both the accelerated degradation factors and resistance to compression. In order to calculate the loss of mass of the specimens, after the 7 day curing period, the blocks were subjected to 6 cycles of 48 hours of wetting in water and drying in an oven. The maximum limit assigned by the Brazilian Standard NBR 13554 is $10 \%{ }^{17}$.

The fracture surfaces of specimens were analyzed by scanning electron microscopy (SEM), in a model $5800 \mathrm{LV}$ Jeol, under an acceleration voltage of $10-15 \mathrm{kV}$.

\section{Results and Discussion}

Table 2 presents the XRF chemical analysis of the investigated limestone residues from marble production. In this table it is shown that the residues are mostly composed of calcium oxide $(\mathrm{CaO})$ and magnesium oxide $(\mathrm{MgO})$, which are characteristic compounds of carbonate rocks ${ }^{19}$. It can 
also be observed that this residues presents a characteristic composition of dolomitic limestone, since the ratio $\mathrm{MgO} / \mathrm{CaO}$ is around 0.19 , i.e., between 0.08 and $0.25^{20}$.

Table 2. XRF Chemical composition of the marble residues

\begin{tabular}{cc}
\hline \multicolumn{2}{c}{ Chemical Composition (\%) } \\
\hline $\mathrm{CaO}$ & 72.56 \\
$\mathrm{MgO}$ & 13.97 \\
$\mathrm{SiO}_{2}$ & 9.75 \\
$\mathrm{~K}_{2} \mathrm{O}$ & 1.46 \\
$\mathrm{Fe}_{2} \mathrm{O}_{3}$ & 1.35 \\
$\mathrm{SO}_{3}$ & 0.81 \\
$\mathrm{Er}_{2} \mathrm{O}_{3}$ & 0.04 \\
$\mathrm{CuO}$ & 0.03 \\
$\mathrm{SrO}$ & 0.03 \\
\hline
\end{tabular}

Figure 2 shows the granulometric distribution of the limestone residues indicating that the amount of clay fraction is of the order of $20 \%$, the silt content is $74 \%$ and the fine sand content is about $6 \%$. The density of the limestone grains was calculated $2.75 \mathrm{~g} / \mathrm{cm}^{3}$. This result reflects the mineralogy of the marble stone and are in accordance to the studies of Ribeiro et al. ${ }^{21}$ that showed that this material could be classified as non-plastic due to the Atterberg boundaries.

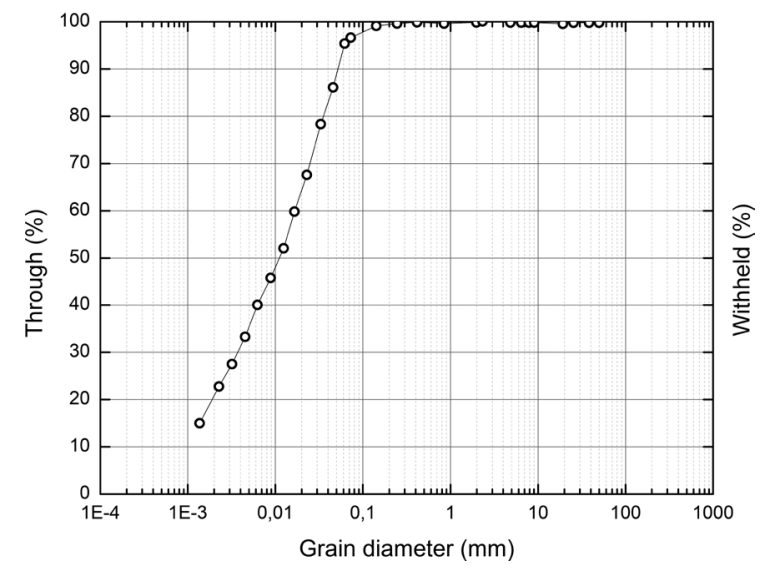

Figure 2. Marble residues granulometric curve

Figure 3 shows the X-ray diffractogram of the limestone residues. It is possible to note the typical peaks of calcite $\left(\mathrm{CaCO}_{3}\right)$ expressed by the letter " $\mathrm{C}$ " and dolomite $\left(\mathrm{CaMg}\left(\mathrm{CO}_{3}\right)_{2}\right)$ indicated by the letter " $\mathrm{D}$ ", which are the main constituents of the carbonate rocks. This result confirms the data presented by the chemical analysis of the material in Table 2 .

The results of the 28 day water absorption tests are shown in Figure 4. In this figure one can verify a decrease in the average value of the water absorption with the addition of

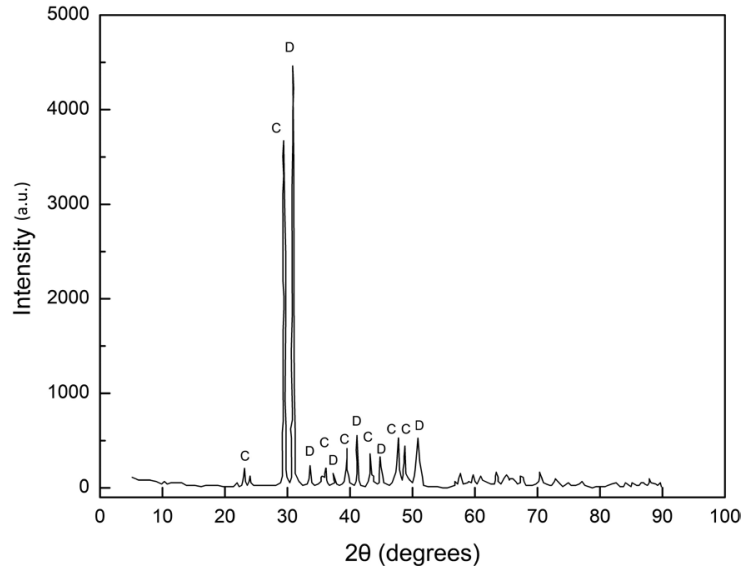

Figure 3. Marble residues X-ray diffractogram

up to $40 \mathrm{vol} \%$ of the limestone residues as compared to the control composition. On the other hand, within the standard deviations it is possible to see a continuous increase of the water absorption for the 30,40 and $50 \mathrm{vol} \%$ compositions. This can be attributed to the porosity of the produced material. It was, however, observed that for all residues incorporations the water absorption values remained within the limits of $20 \%$ required by the Brazilian Standard NBR $10836^{18}$.

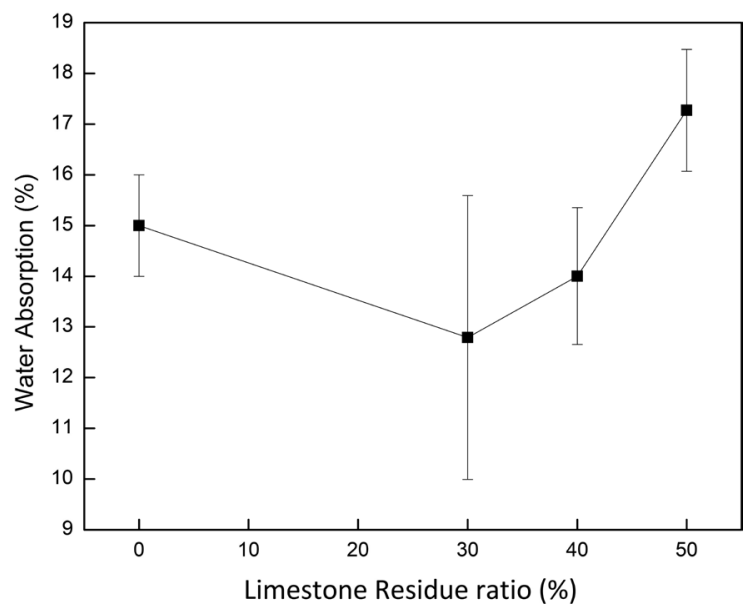

Figure 4. Water absorption curve for all compositions

The variation of the compressive strength with the amount of limestone residues after 28 day of cure is exhibit in Figure 5. One should note that the compressive strength increases with the incorporation of the residues up to the composition with $30 \mathrm{vol} \%$, as compared to the control one. However, with increasing the content of the residues in the mixture in 40 and $50 \mathrm{vol} \%$ there was a decrease in its mechanical resistance. The strength obtained with the incorporation of the residues were higher than $2.0 \mathrm{MPa}$, which is in agreement with the limits defined by the Brazilian Standard NBR $10836^{18}$. 


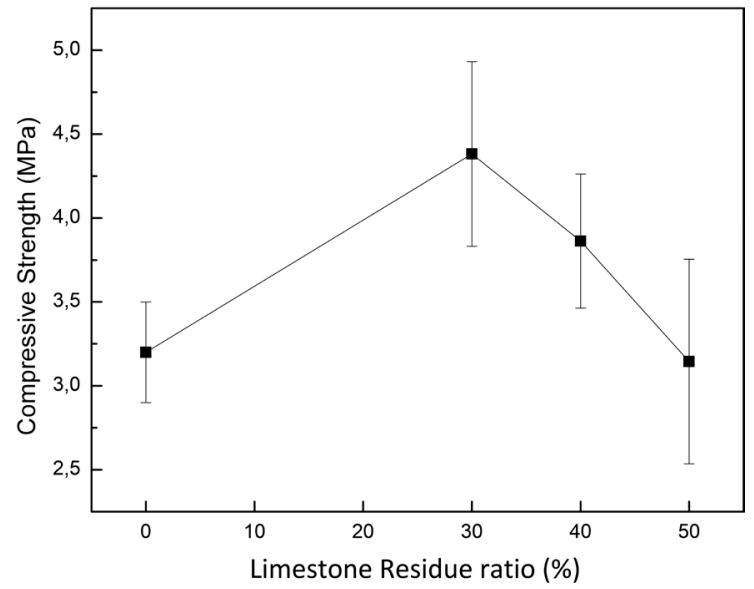

Figure 5. Compressive strength curve for all compositions

The result of the accelerated degradation (durability) test is shown in Figure 6 . This test was performed by successive wetting and drying of the soil-cement blocks and limestone residues in order to obtain the mass loss of the product. As seen in Figure 6, the values attained in the test were below the limit of $10 \%$ stipulated by the NBR 13554 standard $^{17}$. It should also be noticed that with the incorporation of the residues in the soil-cement mixture, the performance in the parameters of durability of the material is increased, in comparison with the control sample. The incorporation of $30 \mathrm{vol} \%$ of the residues into the mixture resulted in a lower mass loss as compared to the 40 and $50 \mathrm{vol} \%$ compositions. This is probably due to their porosity, also indicated by the water absorption test in Figure 4.

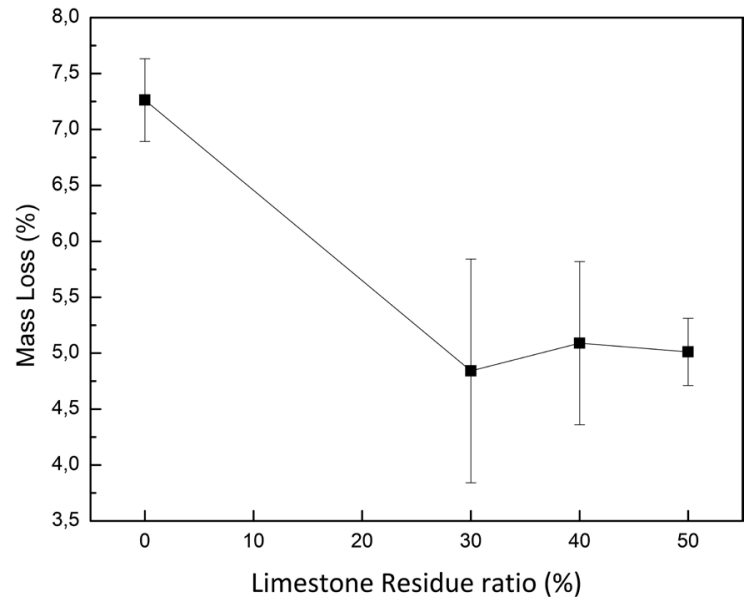

Figure 6. Mass loss obtained by wettability and drying results

The specimens subjected to the durability tests were tested by compression after 28 days of curing. This was conducted in order to obtain an additional resistance parameter after accelerated degradation, for comparison with the samples that were not subjected to degradation. Figure 7 shows the results of compression strength of the degraded specimens as compared to corresponding specimens that were not subjected to degradation. It is surprisingly observed in Figure 7 that the results of compression strength of the specimens subjected to the accelerated degradation test were superior to those obtained for the non-degraded specimens. This can be explained as a consequence of the press conformation of the degraded blocks that are subjected to cycled moisture addition during the durability test. Consequently, the hydration process of the cement particles takes place effectively. Through the successive cycles of wetting and drying the anhydrous cement particles contained in the specimens eventually were hydrated to increase the resistance. It can also be observed in Figure 7 that, for the residues addition of $30 \mathrm{vol} \%$ in the mixture, there was an increase in the compressive strength followed by a slight decrease with the stabilization of the resistance for higher contents. Results like these were also observed by Khodabakhshian et al. ${ }^{22}$, where it was showed that for higher amount of marble residues incorporated, compressive strength and durability tend to be decreased. In spite of these variations, all compressive results for incorporated residue were higher than the control specimen without residues.

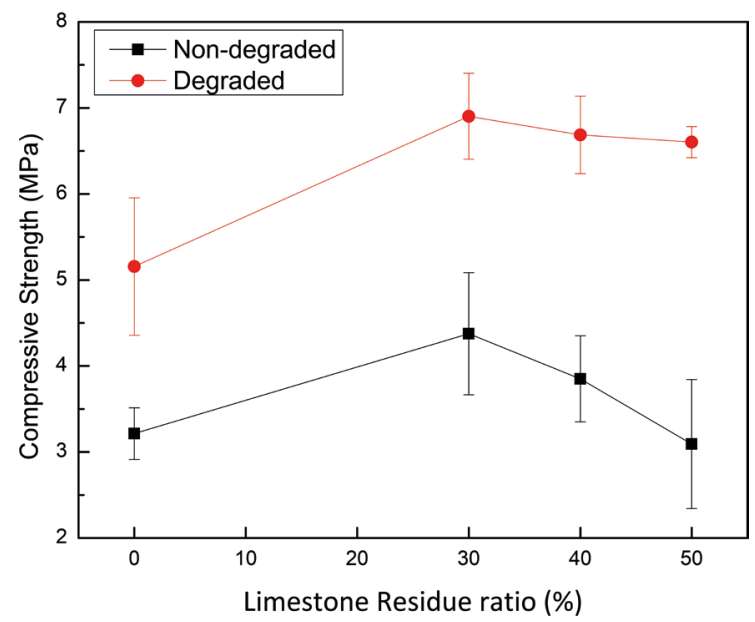

Figure 7. Compressive strength results after degradation

The SEM analysis of the fracture surface of the soil-cement blocks with limestone residues both degraded and non-degraded revealed sensible differences. Figures 8 (a) to (d) present the fracture results for the samples of the soil-cement blocks with $30 \%$ vol incorporation of limestone.

It was verified that in degraded samples subjected to the durability test, Figures 8 (a) and (b), the fractured surface presented through the matrix/aggregate transition zone, good adhesion as well as a denser matrix with few voids and pores. This porosity reduction may be associated with the higher volume of the hydrated compounds of the cement in relation to the volume occupied by the anhydrous phases ${ }^{23}$. For the non-degraded samples that did not undergo the durability test, Figures 8 (c) and (d), one can see that the fracture surface 

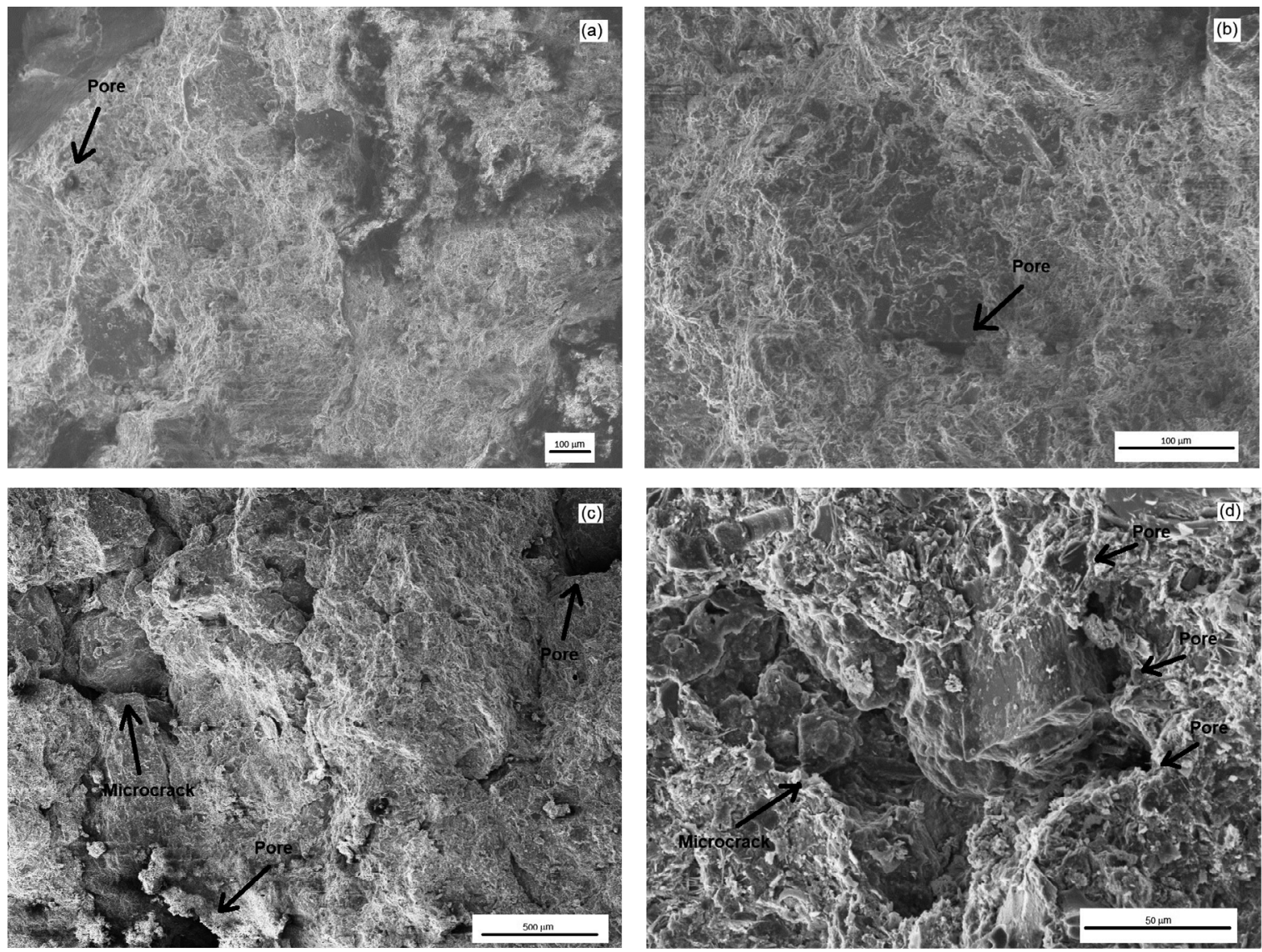

Figure 8. SEM surface analysis

the sample displays through the matrix/aggregate transition zone evidence of low adhesion, which justify the presence of microcracks and pores indicated by arrows.

\section{Conclusions}

- The incorporation of the limestone residues from the processing of marble in the preparation of soilcement blocks is technological feasible. The evaluated parameters of compressive strength, water absorption and durability evidenced a superior performance of blocks with incorporation of residues.

- The content of $30 \mathrm{vol} \%$ of residues incorporation in the mixture presented a well defined benefit in the analyzed parameters.

- With the increase of the residues incorporation in 40 and $50 \mathrm{vol} \%$ it was evident an increase in water absorption and decrease in the mechanical resistance as well as greater loss of mass with respect to the $30 \mathrm{vol} \%$ of residues block.

- Degraded blocks display a significant increase in strength with incorporation of residues as well as a surprising improvement as compared to corresponding non-degraded blocks. This attributed to the low porosity resulting from the wetting and drying cycles of the durability tests in which the hydration of the cement particle is more effective.

- It was also evidenced the tendency of the block to gain strength after the durability test. This is apparently analogous to the resistance gain over time and atmosphere exposure to which the construction block might be subjected after fabrication.

\section{Acknowledgement}

The authors thank the financial support to this investigation by the Brazilian agencies: CNPq, FAPERJ and CAPES.

\section{References}

1. Piazzarollo CB, Xavier GC, Alexandre J, Azevedo ARG, Vieira CMF, Monteiro SN, Braga FO. Factorial Design for $3^{2}$ Experimental Planning of Clay Ceramic Incorporated with Ornamental Stone Waste. Materials Science Forum (Online) 2016; 869:127-130.

2. Buyuksagis IS, Uygunoglu T, Tatar E. Investigation on the usage of waste marble powder in cement-based adhesive mortar. Construction and Building Materials. 2017;154:734-742. 
3. Alexandre J, Azevedo ARG, Xavier GC, Pedroti LG, Vieira CMF, Monteiro SN. Characterization of a Limestone Powder Residue for Recycling as a Concrete Block Incorporation. Materials Science Forum. 2014;798-799:3-8.

4. Carvalho A, Xavier GC, Alexandre J, Pedroti LG, Azevedo ARG, Vieira CMF, et al. Enviromental Durability of Soil-Cement Block Incorporated with Ornamental Stone Waste. Materials Science Forum. 2014;798-799:548-553.

5. Grandi SL. Development of the construction industry in Brazil and changes in the composition of labor and work organization (In Portuguese). In: VIII Encontro Nacional de Engenharia de Produção, 198; 1(3): p. 45-52.

6. Azevedo ARG, Alexandre J, Xavier GC, Monteiro SN, Vieira CMF. Characterization of Wastes from Ornamental Stones for Use in Mortar. In: Carpenter JS, Bai C, Hwang JY, Ikhmayies S, Li B, Monteiro SN, et al., eds. Characterization of Minerals, Metals and Materials. Hoboken: John Wiley \& Sons; 2014. p. 379-386.

7. Dhanapandiana S, Shanthib M. Utilization of marble and granite wastes in brick products. Journal of Industrial Pollution Control. 2009;25(2):145-150.

8. Alves RP, Segantini AAS. Estudo da utilização de resíduos de mármore na composição de tijolos prensados de solo-cimento. In: $26^{\circ}$ Congresso de Iniciação Científica da UNESP; 2014 Nov 26-28; Águas de Lindoia, SP, Brazil.

9. Uygunoglu T, Topçu IB, Çelik AG. Use of waste marble and recycled aggregates in self-compacting concrete for environmental sustainability. Journal of Cleaner Production. 2014;84:691-700.

10. Corinaldesi V, Moriconi G, Naik TR. Characterization of marble powder for its use in mortar and concrete. Construction and Building Materials. 2010;24(1):113-117.

11. Sutcu M, Alptekin H, Erdogmus E, Gencel O. Characteristics of fired clay bricks with waste marble powder addition as building materials. Construction and Building Materials. 2015;82:1-8.

12. Büyüksağiş $S$, Çetintaş $S$, Uygunoğlu T, Işitir A. Use of waste marble powder in cement based ceramic grouting mortar. ElCezerî Journal of Science and Engineering. 2016;3(1):66-74.
13. Oliveira DF, Santos VS, Lira HL, Melo AB, Neves GA. Durabilidade de Compósitos de Concreto de Cimento Portland Produzidos com Agregados Reciclados da Construção Civil. Revista Eletrônica de Materiais e Processos. 2006;1(2):30-36.

14. Lajaruna MAV. Study of self compacting cement-soil for manufacture of marble powder and construction residues bricks. [Dissertation]. São Paulo: Paulista State University; 2016.

15. Marras G, Bortolussi A, Peretti R, Careddu N. Characterization methodology for re-using marble slurry in industrial applications. Energy Procedia. 2017;125:656-665.

16. Brazilian Association of Technical Standards - ABNT (Associação Brasileira de Normas Técnicas). NBR 12023 - Soil-cement Compaction test method. Rio de Janeiro: ABNT; 1992.

17. Brazilian Association of Technical Standards - ABNT (Associação Brasileira de Normas Técnicas). NBR 13554 - Soil-cement Durability test by wetting and drying - Test method. Rio de Janeiro: ABNT; 2012.

18. Brazilian Association of Technical Standards - ABNT (Associação Brasileira de Normas Técnicas). NBR 10836 - Soil-cement block - Dimensional analysis, compressive strength determination and water absorption - Test method. Rio de Janeiro: ABNT; 2013.

19. Menezes RR, Almeida RR, Santana LNL, Ferreira HS, Neves GA, Ferreira HC. Use of kaolin processing waste for the production of ceramic brick and roof tiles. Matéria (Rio de Janeiro). 2007;12(1):226-236.

20. Santos PS. Ciência e Tecnologia de Argilas. São Paulo: Edgard Blucher; 1989.

21. Ribeiro CEG, Rodriguez RJS, Vieira CMF, Carvalho EA, Candido VS, Monteiro SN. Production of Synthetic Ornamental Marble as a Marble Waste Added Polyester Composite. Materials Science Forum. 2014;775-776:341-345.

22. Khodabakhshian A, Ghalehnovi M, De Brito J, Shamsabadi EA. Durability performance of structural concrete containing silica fume and marble industry waste powder. Journal of Cleaner Production. 2018;170(1):42-60.

23. Salum LP. Efeito da elevação de temperatura sobre a resistência à compressão de concretos massa com diferentes teores de cinza volante. [Dissertation]. Florianópolis: Federal University of Santa Catarina; 2016. 